\title{
Genetic Variation Based on RAPD Profiling and Production Loss of Cayenne Pepper due to Periodic Flooding
}

\author{
Muhammad Rizza Pahlevia, ${ }^{\mathrm{a},{ }^{*}}$, Serafinah Indriyani ${ }^{\mathrm{b}}$, Retno Mastuti ${ }^{\mathrm{b}}$, Estri Laras Arumingtyas ${ }^{\mathrm{b}}$ \\ ${ }^{a}$ Department of Agrotechnology, University of Kahuripan, Kediri, 64213, Indonesia \\ ${ }^{b}$ Department of Biology, Faculty of Mathematics and Natural Sciences, Brawijaya University, Malang, 65145, Indonesia \\ Corresponding author: *pahlevi_mr@student.ub.ac.id
}

\begin{abstract}
Cayenne pepper is known as a sensitive plant to water stress, either drought or flooding. However, not many studies on the plant's response to the naturally occurring periodic flooding have been reported to date. This study aimed to determine the agronomic and genetic response of cayenne pepper against periodic flooding and find whether RAPD profile reflects periodic flooding endurance. Three cultivars of cayenne pepper: Cakra Hijau (CH); Mhanu XR (M); and Sret (S) were used. Plants were treated with periodic flooding Po (one day of flooding followed by two days of drainage), P1 (2 x P0), and P2 (3 x P0), and C as control. A completely randomized design was used for the experiment, and the data obtained were analyzed statistically. Plant height and the number of fruits between the control and every flooding treated plant were significantly different, indicating that periodic flooding caused the delay of stem growth and decreased fruit number of all cultivars. The number of branches was influenced significantly by periodic flooding. In contrast, the plant survival rate showed no significant difference among all treatments. The higher the periodic flooding, the higher the risk of plant death and increased risk of production loss. Jaccard's clustering on RAPD profiling indicated that the group was developed based on cultivar more than periodic flooding. It was concluded that $\mathrm{CH}$ differed from others and had better endurance against periodic flooding, made it a right candidate for a breeding program.
\end{abstract}

Keywords - Cayenne pepper cultivars; climate change; periodic flooding; production loss; RAPD.

Manuscript received 6 Feb. 2020; revised 14 Jul. 2020; accepted 24 Feb. 2021. Date of publication 30 Apr. 2021. IJASEIT is licensed under a Creative Commons Attribution-Share Alike 4.0 International License.

\section{INTRODUCTION}

Cayenne pepper or chili pepper, or cabai rawit in Indonesia [1], is one of the horticulture crops reported as being susceptible to water stress [2], not only to lack of water [3], but also excessive water stress [4]. There are two cayenne pepper species known in Indonesia, i.e., Capsicum annuum L. and Capsicum frutescens L. [5]. Cayenne pepper could be distinguished morphologically by their corolla's color, another color, the form of their fruit stalks, and their leaves' shape [1].

The increase of duration and frequency of heavy rainfalls due to climate change results in flooding stress [6], with climate change, therefore, having been reported to cause the decrease of the production of cayenne pepper [7]. Flooding stress affects crop production, and it becomes a global problem [8], with partial and complete flooding bringing negative effects to plants due to growth inhibition and crop production losses [9]. Besides, the flooding causes wilting and leads to the cayenne pepper plant's death [4].
Flooding causes limitations of gas exchange in roots makes the energy and carbohydrate deficits [6]. It leads to the oxygen-deficient conditions of both hypoxia and anoxia in roots. It increases the hydrogen peroxide $\left(\mathrm{H}_{2} \mathrm{O}_{2}\right)$ levels. The hydrogen peroxide is one of the less-radical ROS (Reactive Oxygen Species) groups. The main radical ROS groups include superoxide anion or superoxide radical and hydroxyl radical [10]. Hydrogen peroxide is the source of a more active ROS, namely hydroxyl radical $(\bullet \mathrm{OH})$ through the Fenton and Haber-Weiss reaction [11]. Non-photosynthetic tissue becomes the primary source of $\mathrm{H}_{2} \mathrm{O}_{2}$ due to the activation of $\mathrm{NAD}(\mathrm{P}) \mathrm{H}$ oxidation and disruption in the electron transfer chain. In hypoxic conditions, interference with the electron transfer chain in the mitochondria increases $\mathrm{H}_{2} \mathrm{O}_{2}$, causing cells to undergo oxidative stress [12], [13]. Hydrogen peroxide is known to cause large changes in gene expression levels in plants [14], [15]. Oxidative stress due to high ROS concentrations damages macromolecules such as lipid, protein, and DNA. ROS oxidizes deoxyribose, damages strands, and eliminates nucleotides and base modification in DNA [16]. There are several techniques for investigating the 
genetic diversity that one can use, one of which is the Random Amplified Polymorphic DNA, and the above events are possible causes of genetic diversity.

With the Random Amplified Polymorphic DNA (RAPD) as a molecular marker was used for several studies, such as hybrid identification in chili [17], genetic diversity of Capsicum [18]-[20], hybrid purity test of C. annuum [21], [22], a variety of Durio zibethinus Murr. [23], and genetic changes in C. annuum mutants [24]. RAPD application is easy and inexpensive. This is owing to it not using radioactive probes and does not require prior knowledge of gene sequences [17]. There were few studies of cayenne pepper in previous literature against periodic flooding but no information related to its genetic profile. This study aims to determine the agronomic response of cayenne pepper against periodic flooding due to climate change and confirm whether the RAPD-genetic profiling reflects the endurance of cayenne pepper against periodic flooding.

\section{MATERIALS AND METHODS}

\section{A. Materials}

Three cultivars of cayenne pepper with different characteristics, Cakra Hijau (CH), Mhanu XR (M), and Sret (S) were used (Table I). All cultivar's seedlings were grown in a greenhouse using plant media with a composition comprising soil, compost, manure from goat dung, and husk charcoal $(2: 1: 1: 1)[4]$.

TABLE I

MORPHOLOGICAL CHARACTERISTICS OF CAYENNE PEPPER BASED ON TYPE OF FRUIT ORIENTATION AND COLOR OF THE FRUIT, FLOWER, AND SEEDS

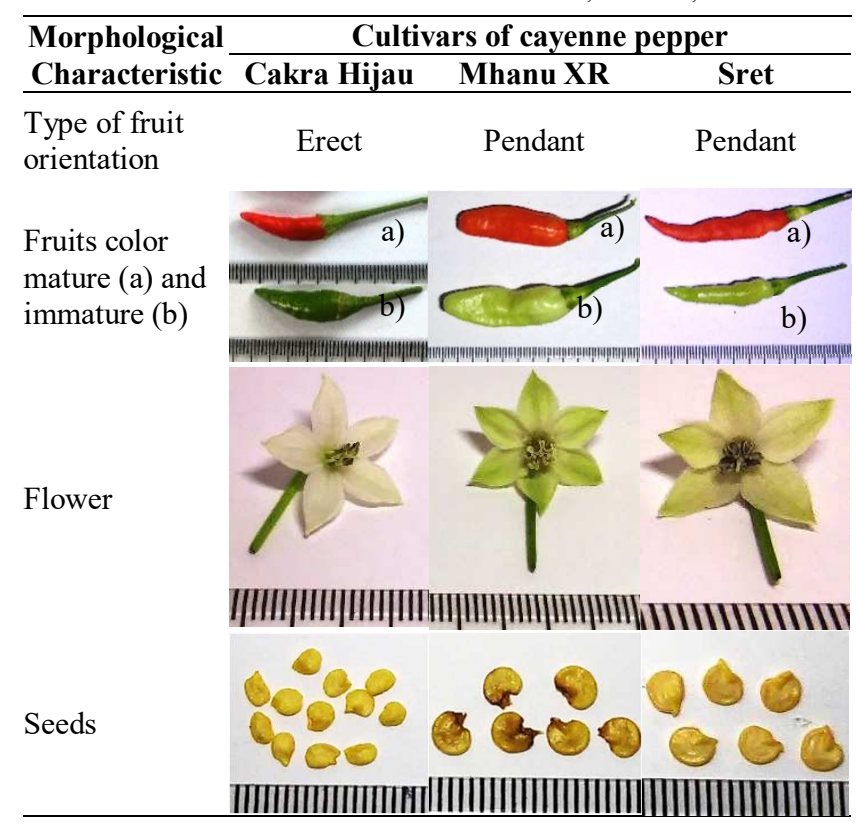

\section{B. Experimental Design}

The experiment used a completely randomized design. Plants are grown in an organic-conversed management system and bioorganic pesticides for pest and disease management. All 30 DAS (days after sowing) seedlings from three cultivars were transplanted with one plant in one pot (approximately $35 \mathrm{~cm}$ of diameter) as 0 DAP (days after planted). Thirty DAP plants were treated with four levels of periodic flooding treatment such as control, which was non- flooding plants, P0 (plants treated with one day of flooding and followed with two days of drainage), P1 (plants treated with P0 treatment, with two times repetition), and P2 (plants treated with $\mathrm{P} 0$, with three times repetition). Each was executed with eight replications/treatment (Fig. 1) using a completely randomized design, as described on Pahlevi et al. [4]. Flooding treatment was carried out using tap water with a depth around $13 \mathrm{~cm}$ from the water surface or partial flooding Pahlevi et al. [4]. During the experiment, the range of temperature and relative humidity $(\mathrm{RH})$ inside the greenhouse was $20.9^{\circ} \mathrm{C}-40.3^{\circ} \mathrm{C}$ and $30.7 \%-99.0 \%$, respectively.

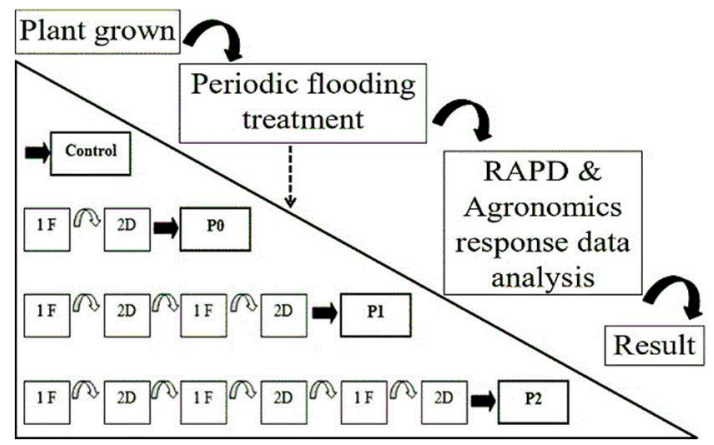

Fig. 1 Experiment flowchart and periodic flooding treatments scheme Control $=$ non-flooded treatment, $\mathrm{P} 0=$ periodic flooding $\mathrm{P} 0$ (flooding treatment, treated with 1 day of flooding followed by 2 days of drainage), P1 = periodic flooding P1 ( 2 times P0), P2 = periodic flooding P2 (3 times P0), $1 \mathrm{~F}=1$ day flooded-plants, $2 \mathrm{D}=2$ days drained-plants after flooding.

\section{Agronomy Parameters}

The effects of periodic flooding treatments were observed on agronomic response and RAPD profiling. Agronomic parameters related to production loss were plant height, the number of branches, the number of fruits, and the ratio of death and survived plants. Plants in serious conditions suffering from the disease were excluded from data recording. Plant height was observed by measuring the plant's height from the stem base until the highest apex, referring to Sujitno and Dianawati [25], started after treatment periods, and plant height was observed periodically were collected at 51 DAP. The number of plants branches was counted manually at 51 DAP. Death plants were counted, referring to Susilawati et al. [26] from the first treatment periods until the first harvesting periods. The number of fruits per plant was counted each harvesting time from the first harvesting time until the end harvesting time in one cycle harvesting periods.

\section{DNA Isolation}

Young leaf tissue collected after each flooding treatment was used for DNA isolation. DNA isolation was performed using cetyltrimethylammonium bromide (CTAB) methods referring to Sundari et al. [23], with modification. A total of $0.1 \mathrm{~g}$ of young leaf tissue was ground with pestle and mortar within liquid nitrogen. As much as $700 \mu 1$ pre-heated CTAB buffer extract was added to ground leaves' tissue. Leaves' extract was transferred into microtubes, vortexed, and incubated at $65^{\circ} \mathrm{C}$ for $30 \mathrm{~min}$. Homogenate was centrifuged at $13,000 \mathrm{rpm}$ for $10 \mathrm{~min}$ at $4^{\circ} \mathrm{C}$. The supernatant was added with PCI v/v, vortexed and centrifuged for $5 \mathrm{~min} 4^{\circ} \mathrm{C}$ at $13,000 \mathrm{rpm}$. The supernatant was added CI (v/v), vortexed and centrifuged $13,000 \mathrm{rpm}$ at $4^{\circ} \mathrm{C}$ for $5 \mathrm{~min}$. The ammonium acetate $7.5 \mathrm{M}$ and ethanol absolute was added $0.1(\mathrm{v} / \mathrm{v})$ to 
supernatant followed by incubation at $-20^{\circ} \mathrm{C}$ overnight for DNA precipitation. The supernatant was centrifuged at $13,000 \mathrm{rpm} 4^{\circ} \mathrm{C}$ for $15 \mathrm{~min}$. Pellet was washed using ethanol $70 \%$ by inverting and then centrifuged at $13,000 \mathrm{rpm}$ for 10 min at $4^{\circ} \mathrm{C}$. Pellet was air-dried and then re-suspended with $20 \mu \mathrm{T}$ TE. DNA was then stored at $-20^{\circ} \mathrm{C}$ for DNA analysis.

\section{E. RAPD Analysis}

Program settings and primers used for RAPD refer to Sikora and Nowaczyk program [17]. Seven screenedpolymorphic primers were used, such as OPA4, OPA7, OPA8, OPA11, OPA12, OPA14, OPA15. Program settings for RAPD were as follow: Pre-denaturation $91^{\circ} \mathrm{C}$ for $1 \mathrm{~min}$, continued with 38 cycles consisting of denaturation $91{ }^{\circ} \mathrm{C}$ for $15 \mathrm{~s}$, annealing $42^{\circ} \mathrm{C}$ for $15 \mathrm{~s}$, extension $72^{\circ} \mathrm{C}$ for 1 min $10 \mathrm{~s}$, and final extension $72^{\circ} \mathrm{C}$ for $5 \mathrm{~min}$. A $10 \mu$ of RAPD cocktail was used with composition of $3 \mu \mathrm{lddH} 2 \mathrm{O}, 5 \mu \mathrm{l}$ PCR master mix (Intron), primer OPA $1.5 \mu \mathrm{l}$ with concentration 10 $\mathrm{pmol} / \mu \mathrm{l}$, and DNA template $0.5 \mu \mathrm{l}$ with DNA concentration around $500 \mathrm{ng} / \mu \mathrm{l}-1,000 \mathrm{ng} / \mu \mathrm{l}$.

\section{RESULT AND DISCUSSION}

\section{A. Plant Height}

The plant height was significantly influenced by the interaction between cultivars and periodic flooding treatments $(p<0.05)$ (Fig. 2A). The averages of plant height of the control, P0, P1, and P2 of CH were $67.69 \mathrm{~cm}, 56.50 \mathrm{~cm}, 56.17$ $\mathrm{cm}$, and $51.10 \mathrm{~cm}$, respectively; Mhanu XR (M) were control, $\mathrm{P} 0, \mathrm{P} 1$, and $\mathrm{P} 2,61.13 \mathrm{~cm}, 48.20 \mathrm{~cm}, 43.00 \mathrm{~cm}$, and $42.50 \mathrm{~cm}$, respectively; and Sret were $69.38 \mathrm{~cm}, 52.50 \mathrm{~cm}, 54.67 \mathrm{~cm}$, and $50.50 \mathrm{~cm}$, respectively. Control of all cultivars was significantly different from all periodic flooding treatments (P0, P1, and P2). The plant height among cultivars was significantly influenced $(p<0.05)$, with average $\mathrm{CH}$ at 58.92 $\mathrm{cm}, \mathrm{M}$ at $50.33 \mathrm{~cm}$, and $\mathrm{S}$ at $58.48 \mathrm{~cm}$ (Fig. 2B). Cultivar M was significantly different from $\mathrm{CH}$ and $\mathrm{S}$. It showed the diversity of plant height responses among cayenne peppers when facing periodic flooding.

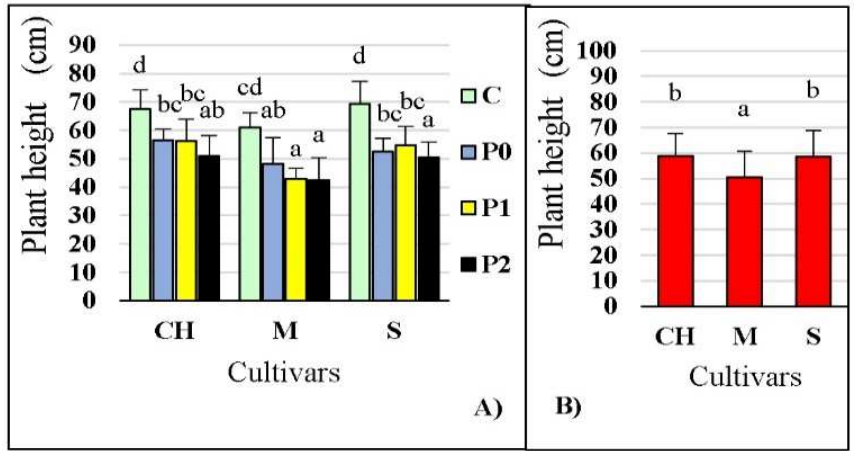

Fig. 2 Plant height response of cayenne pepper cultivated varieties (cultivars) in several types of periodic flooding stress (A) and among cultivars (B). $\mathrm{CH}$ $=$ Cakra Hijau, $\mathrm{M}=$ Mhanu $\mathrm{XR}, \mathrm{S}=$ Sret. $\mathrm{P} 0=\mathrm{P} 0$ periodic flooding, $\mathrm{P} 1=$ periodic flooding P1, and P2 = periodic flooding P2. Different letters showed significant difference based on statistical test $(p<0.05)$.

Periodic flooding P0, P1, and P2 provided the same effect on the height of all cultivars of cayenne pepper (Fig 2). Plants experiencing periodic flooding $\mathrm{P} 0$ to periodic flooding $\mathrm{P} 2$ showed the same height, indicating that the first flooding still affected (P0) plants on periodic $\mathrm{P} 2$, and repeated flooding within a short period did not significantly affect the plants. However, waterlogging stress during the generative stage of red chili pepper varieties was reported to significantly decrease plant height in line with the increased waterlogging stress duration [27]. Although the plant height within the cultivar was similar among periodic flooding ( $\mathrm{P} 0, \mathrm{P} 1$, and $\mathrm{P} 2)$, when the plants were flooded for the first time and followed by quick drainage, it caused physiological disturbance within the plant; hence the plant suffered from multiple stress.

Flooding followed by drainage generated stress for the plants. Plants submerged in water will be deprived of oxygen and suffer from multiple stresses such as slow gas diffusion, accumulation of toxic end product, high risk for diseases infection. Then, when followed by drainage, plants were immediately exposed to high oxygen concentrations and plants suffered from dehydration, high risk of pests, diseases, etc. In this condition, the plants suffered from a post-flood injury due to oxidative stress [13], [28]-[30]. To survive these conditions, the plant tries to deal with oxidative stress by the limited energy and finally results in a delay in plant height growth.

It seems that cayenne pepper showed a quiescence strategy against flooding stress. Growth quiescence is a strategy in temporary flooding due to conserving energy [31]. However, there was no significant difference among periodic flooding treatments ( $\mathrm{P} 0, \mathrm{P} 1$, and $\mathrm{P} 2)$, but there was a tendency to decrease plant height. The same phenomenon was also reported in tomatoes, where there was a decrease in plant height due to waterlogging in different stress duration levels [32], [33]. In contrast, a decrease in plant height significantly occurred in tobacco varieties due to waterlogging [34]. These differences might be due to differences in flooding treatment, species, and also different environments. While in soybean (Glycine max), hampering in plant height due to repeated temporary flooding was higher than hampering due to saturated soil culture [35]. Flooding also hampered the plant height of Solanum dulcamara [36]. As mentioned by Barickman et al. [37], waterlogging decreased cucumber plant height significantly.

\section{B. Number of Branches}

The number of branches significantly decreased by periodic flooding $(p<0.05)$ (Fig. 3A). Average branches number of $\mathrm{CH}$ (Control, P0, P1, P2) were 21.50, 16.17, 9.33, 8.00 , respectively; $M$ 5.75, 4.40, 3.80, 4.00, respectively, and $\mathrm{S} 12.75,4.80,4.83,3.00$, respectively. Branches number of $\mathrm{CH}$ and $\mathrm{S}$ decreased significantly. Periodic flooding P1 did begin to influence branches number significantly in $\mathrm{CH}$, but in $\mathrm{S}$, it started in $\mathrm{P} 0$. In $\mathrm{M}$, all treatments showed the same responses. Branches number of cultivars $\mathrm{CH}$ was significantly different from $\mathrm{M}$ and $\mathrm{S}$, with the average value of $\mathrm{CH}, \mathrm{M}$, and $\mathrm{S}$ being 14.60, 4.65, and 7.08, respectively (Fig. 3B).

The more often flooding occurred, the more the plant suffered, which then affected branch development, and therefore frequent flooding, which happened in short intervals, gave rise to a bad effect on the number of branches of cayenne pepper. The decrease in branch number also took place in red chili under waterlogging stress conditions; the longer the stress suffered by red chili, the fewer branches it tended to have [26], [27]. Decreased branches per plant also occurred in 
the soybean variety, which was caused more by repeated temporary flooding compared with saturated soil culture [35].

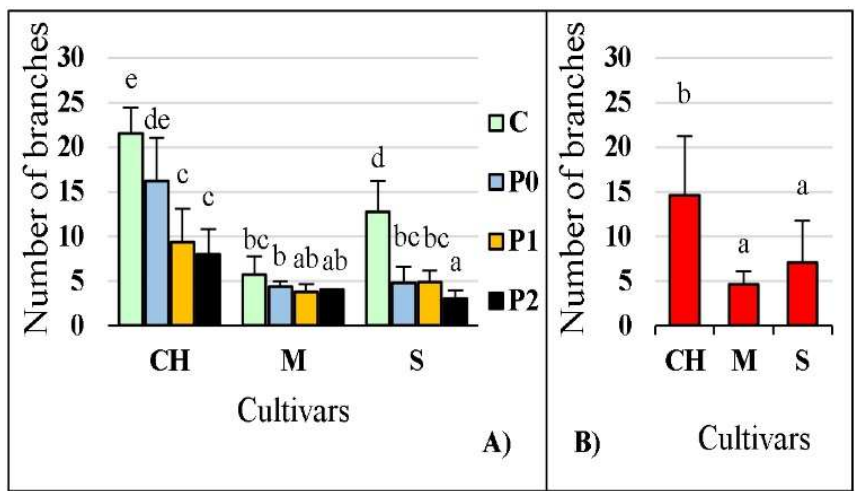

Fig. 3 Plants branches response of cayenne pepper cultivars based on periodic flooding (A) and based on cultivars (B). Cakra Hijau (CH) cultivar, Mhanu XR (M) cultivar, Sret (S) cultivar in several treatments of periodic floodings such as Control, P0, P1, and P2. The different letters show statistically significant differences $(p<0.05)$.

\section{Ratio of Survive and Death Plants}

The ratio of survived and death plants indicated the same responses by the interaction between cultivars and periodic flooding $(p>0.05)$, with the average of survived plants (\%) (control, P0, P1, and P2) in $\mathrm{CH}$ for all treatments being $100 \%$, but in $\mathrm{M}$ the averages were $100.00 \%, 75.00 \%, 75.00 \%$, and $62.50 \%$, respectively, and in $\mathrm{S}$ the averages were $100.00 \%$, $87.50 \%, 75.00 \%$, and $62.50 \%$, respectively (Fig. 4 A). Hence, there was a tendency to increase plant death, especially in $\mathrm{M}$ and $\mathrm{S}$ and therefore $\mathrm{CH}$ had relatively better endurance than two other cultivars. Among cultivars, $\mathrm{CH}$ had significantly better resistance to periodic flooding than $\mathrm{M}$ and $\mathrm{S}$ with a significance value of $0.025(p<0.05)$ (Fig. 4B) with the percentage average of surviving plants of $\mathrm{CH}, \mathrm{M}$, and $\mathrm{S}$ being $100.00 \%, 78.13 \%$, and $81.25 \%$, respectively. Thence the increasing level of periodic flooding increased the potential for plant mortality, especially in M and S. In periodic flooding, $\mathrm{CH}$ was more sustainable than $\mathrm{M}$ and $\mathrm{S}$. The decrease in surviving plants also took place in red chili suffering from waterlogging stress (vegetative stage and generative stage). The longer the stress duration suffered by the red chili plants, the more deaths occurred [26], [27]. In tomato, the death occurrence varied among tomato genotypes, i.e., death plant occurred in flood-intolerant tomato in short time of flooding stress [32].

Lack of oxygen disrupts energy supply, ion transport, and membrane integrity, giving rise to nutritional deficiencies in roots and in shoots [38], and plant death occurs due to this lack of oxygen, which results in an energy crisis in the root. Flooding causes increasing severity of diseases [39], and due to the inability of plants to handle the severity and duration of stress, it leads to plant death [6]. Furthermore, death response in periodic flooding causes multiple stress in plants, not only by submergence (flooding) followed by de-submergence (drainage) but also by the presence of more pest and disease infection in high humidity environments post-flooding [28]. In climate change challenges, flooding coupled with high temperature causes plants to undergo rapid wilting and death [40].

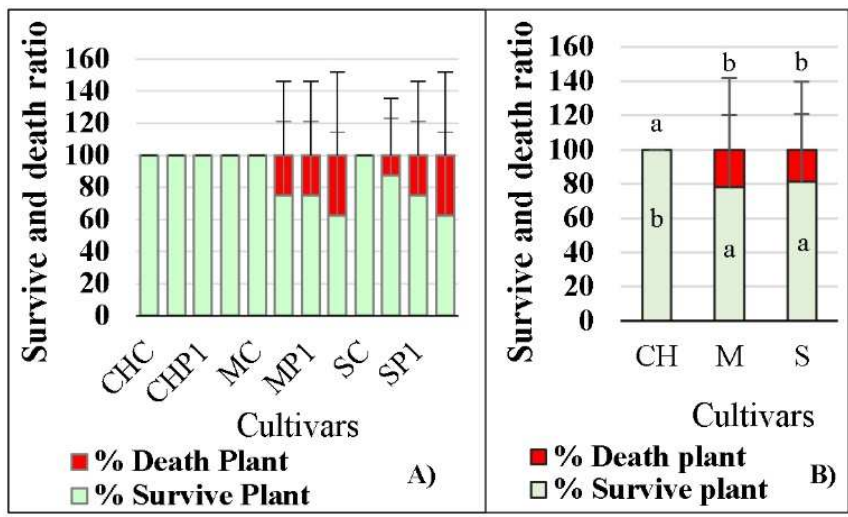

Fig. 4 Ratio of surviving and death plants of cayenne pepper among cultivars and periodic flooding interactions (A) and cultivars (B). Cakra Hijau (CH), Mhanu XR (M), and Sret (S) at periodic flooding treatments (control, periodic $0[\mathrm{P} 0]$, periodic $1[\mathrm{P} 1]$, and periodic $2[\mathrm{P} 2])$. No different letter means no significant difference $(p>0.05)(\mathrm{A})$ and different letter shows significant difference based on statistical test $(p<0.05)(\mathrm{B})$.

\section{Number of Fruits per Plant}

The number of fruits per plant significantly decreased by periodic flooding $(p<0.05)$, especially $\mathrm{M}$, between the control and other treatments ( $\mathrm{P} 0, \mathrm{P} 1$, and $\mathrm{P} 2)$. The average fruits number per plant in $\mathrm{CH}$ (control, $\mathrm{P} 0, \mathrm{P} 1$, and $\mathrm{P} 2$ ) was $166.25,104.00,111.00$, and 101.75 , respectively, in $\mathrm{M}$ was $178.00,69.00,72.00$, and 53.75 , respectively, and $\mathrm{S}$ was $168.00,140.25,86.00$, and 66.67 , respectively (Fig. 5A). Although, there was the same response among treatments in $\mathrm{CH}$. There were significant different responses between control and P1 and P2 in S, although there were also the same responses among $\mathrm{P} 0, \mathrm{P} 1$, and $\mathrm{P} 2$. There were no significant differences in fruits among cultivars $\mathrm{CH}, \mathrm{M}$, and $\mathrm{S}$, and the average was $120.75,106.63$, and 120.79 , respectively (Fig. $5 B)$.

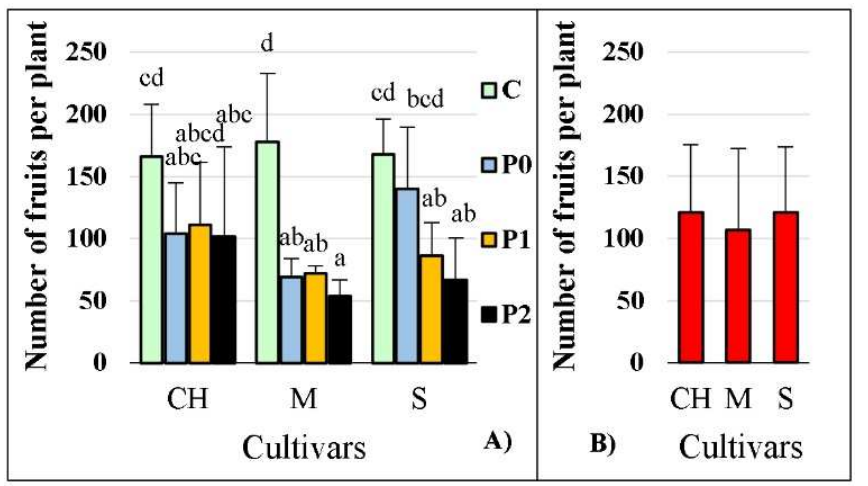

Fig. 5 Potential fruits number per plant of cayenne pepper cultivars $(\mathrm{CH}=$ Cakra Hijau, $\mathrm{M}=$ Mhanu XR, and $\mathrm{S}=\mathrm{Sret}$ ) due to periodic flooding with several levels $(\mathrm{C}=$ control, $\mathrm{P} 0=$ periodic flooding $\mathrm{P} 0, \mathrm{P} 1=$ periodic flooding $\mathrm{P} 1$, and $\mathrm{P} 2$ = periodic flooding $\mathrm{P} 2)$. The different letter means significant difference based on statistical tests $(p<0.05)$.

This study indicated that periodic flooding had the potential to reduce the fruit number found in cayenne pepper. Although there was a tendency of decrease in fruits number, it seemed that periodic flooding had no significant effect in $\mathrm{CH}$ compared with $\mathrm{S}$ and $\mathrm{M}$. With the most falling flowers and fruits caused by flooding treatment and other stress, i.e., disease infection, $\mathrm{M}$ was the cultivar most affected among the others by periodic flooding (Fig. 5A). According to [28], 
flooding and post flooding increase pathogen infection and insect attack.

Decrease of fruits number due to flooding not only occurred in cayenne pepper but also in some red chili varieties under waterlogging stress [26], tomato intolerance to flooding was evidenced after the duration of continuous flooding [32], cape gooseberry (Physalis peruviana L.) in line with increased days of waterlogging [41]. The decrease in fruit number began to occur since the cayenne pepper flooded for the first time. The increasing frequency of periodic flooding can reduce the fruit's number of cayenne pepper, which is detrimental to farmers. In China, C. annuum L. farming has great $C$. annuum production and quality losses due to waterlogging [42].

Production losses in all cultivars of cayenne peppers varied. $\mathrm{CH}$ suffered lower production losses than other cultivars (M and $\mathrm{S}$ ) after periodic flooding. $\mathrm{CH}$ has more endurance in periodic flooding than $\mathrm{M}$ and $\mathrm{S}$. $\mathrm{M}$ and $\mathrm{S}$ had slightly different production losses, with $\mathrm{S}$ having a better response in the number of fruits per plant than $\mathrm{M}$.

\section{F. RAPD Profiling}

RAPD bands' patterns were different between cultivars but similar among flooding treatments within cultivars (Figs. 6 AG). There were several different treatments, but the band pattern within the cultivars was the same. Band pattern profiling showed some uniqueness, which was only possessed by specific particular cultivars (Table II). Several unique bands belonged only to $\mathrm{CH}$ but not others; for example, bands with the size around $220 \mathrm{bp}, 300 \mathrm{bp}, 360 \mathrm{bp}, 830 \mathrm{bp}$, and 1110 bp as the amplicon products OPA12. $\mathrm{CH}$ was also having other unique bands, which were amplified by other primers such as OPA15 (480 bp and $650 \mathrm{bp})$; OPA4 (530 bp, $570 \mathrm{bp}$, 620bp); OPA7 (450 bp, 600 bp, 870 bp); OPA8 (500 bp, 970 bp, 1270 bp); and OPA11 (250 bp, 330 bp, 630 bp, 840 bp). Other unique bands belonged to both cayenne pepper cultivars ( $\mathrm{M}$ and $\mathrm{S}$ ) but were absent in $\mathrm{CH}$, such as; a band with the size around $860 \mathrm{bp}$ of OPA14; band size around (260 bp, $310 \mathrm{bp}$, $400 \mathrm{bp}, 430 \mathrm{bp}, 700 \mathrm{bp}$, and $810 \mathrm{bp}$ ) of OPA12; band size around (500 bp and $630 \mathrm{bp}$ ) of OPA15; band size around (600 bp and $660 \mathrm{bp}$ ) of OPA4; band size around (750 bp, $800 \mathrm{bp}$, $900 \mathrm{bp}$ ) of OPA7; band size around (430 bp and $1000 \mathrm{bp}$ ) of OPA8; and band size around (1700 bp) in OPA11. These unique bands occurred almost in each flooding treatment (control, P0, P1, and P2) in both cultivars.

Jaccard's similarity test of interaction between periodic flooding treatment and cultivar (Fig. 7) showed that the group developed was more based on cultivars than periodic flooding treatments. Control and P2 treatments such as $\mathrm{CC}$ with $\mathrm{CP} 2$, $\mathrm{MC}$ with MP2, or SC with SP1 were grouped close together. Due to periodic flooding treatment, ROS activity was not at the level to alter or disrupt DNA although some plants were dead; control plants that showed no death responses had close position treatment plants (MP2 and SP1) that showed dead responses (Table III and Table IV). The death responses might occur because of plants' lack of adaptive capability in each cayenne pepper cultivar. A previous study using mutagenic treatment successfully produced polymorphic bands in Chili (C. annuum). Such band polymorphism was due to variation in a band, the disappearance of bands reducing or altering the binding sites of Taq polymerase and appearance of new bands due to DNA structural alteration [43].
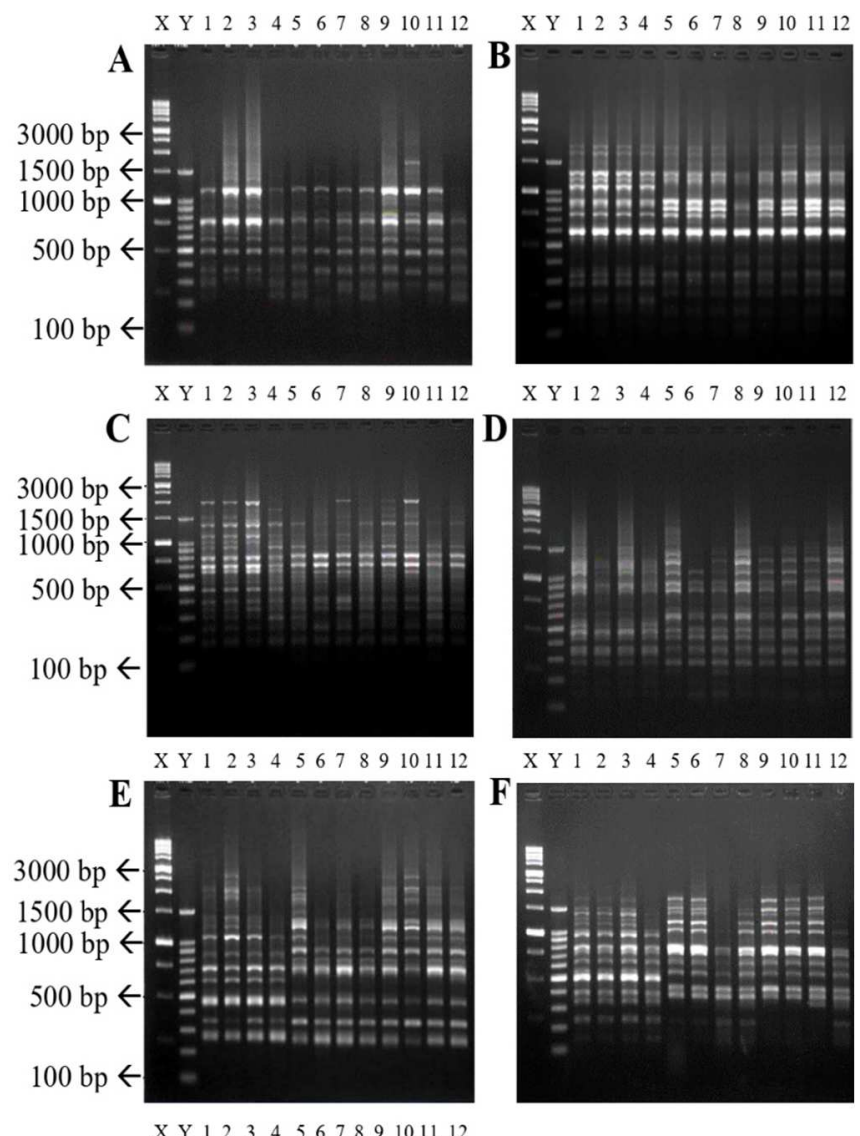

$\mathrm{X} Y \mathrm{Y} 122344566789101112$

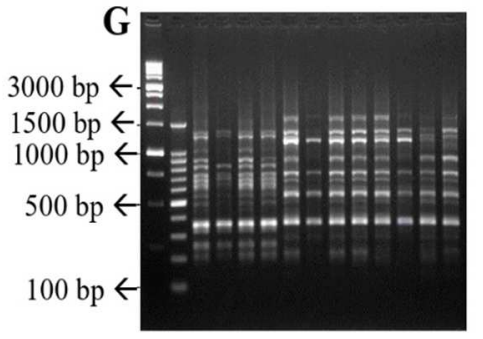

Fig. 6 RAPD profiling using OPA14 (A), OPA12 (B), OPA15 (C), OPA4 (D), OPA7 (E), OPA8 (F), OPA11 (G) of 3 cayenne pepper cultivars (Cakra Hijau, Mhanu XR, and Sret) in $1.5 \%$ agarose electrophoresis. $\mathrm{X}=$ DNA Marker $1 \mathrm{~Kb}$, $\mathrm{Y}=$ DNA Marker 100bp, and well 1-12: CHC (Cakra Hijau Control), CP0, CP1, CP2, MC (Mhanu XR Control), MP0, MP1, MP2, SC (Sret Control), $\mathrm{SP} 0, \mathrm{SP} 1$, and SP2 respectively.

The clustering analysis showed two groups, which appear to be based on cultivars and not by treatment, $\mathrm{CH}$, and $\mathrm{M}-\mathrm{S}$ group (Fig. 7). Based on morphological characteristics (Table I), $\mathrm{CH}$ group has different fruit orientation, mature and immature fruit color, flower color, and seed appearance, differences in response on branch number, surviving and death responses against periodic flooding treatment compared with $\mathrm{M}$ and S cultivars (Fig. 3 and Fig. 4). $\mathrm{CH}$ seemed more enduring against periodic flooding than $\mathrm{M}$ and S. Cultivars $\mathrm{M}$ and $\mathrm{S}$ have a close morphological appearance despite some different characteristics such as fruit appearance and slightly different response against periodic flooding treatment (Fig. 2; Fig. 3; Fig. 5).

It seems that RAPD methods are reliable in distinguishing among cayenne peppers. However, clustering based on RAPD 
band profiles is not directly related to the expression of plant response to the flooding treatment and may not be used to reference plant adaptation to specific periodic flooding stress. Although, more enduring cultivars against flooding stress had different genome profiling. Likewise, RAPD methods were reported reliable to distinguish genetic diversity among cultivars in the same species of chili in India [20], effective for identification of closely related pepper varieties [44], reliable in accessions of hot chili pepper (C. frutescens) characterization in Brazil and become a valuable tool in breeding programs [45].

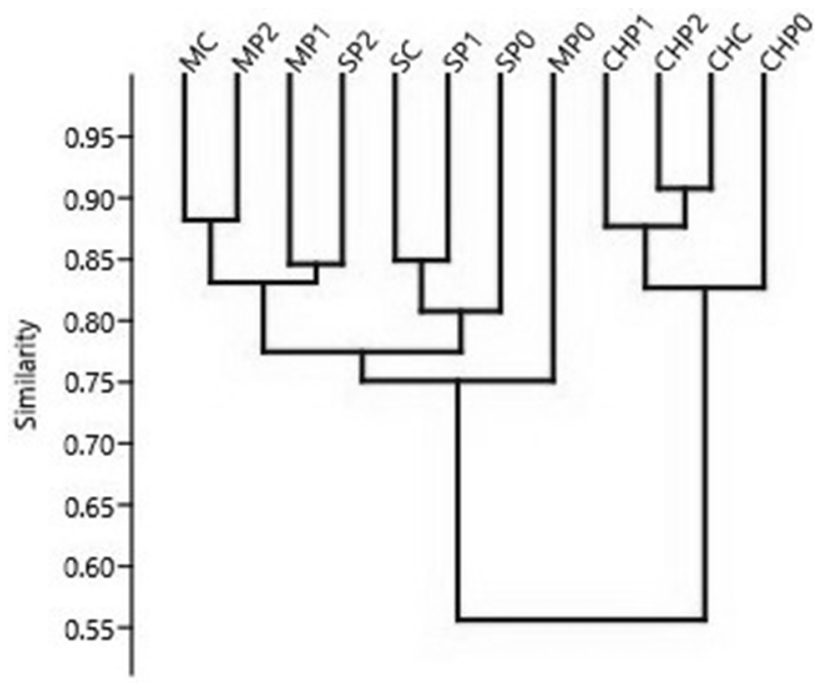

Fig. 7 UPGMA clustering based on RAPD band profile using Jaccard's similarities test

Individual variations in these cultivars might cause the band profile differences within cultivars both in the same and different flooding treatment. This research was recommended to conduct further studies to verify $\mathrm{CH}$ cultivars into an appropriate nomenclature system since $\mathrm{CH}$ cultivar had different band profiles with other $C$. frutescens L. cultivars (Fig. 7), although some said that it is a cultivar of $C$. frutescens [46].

The response or adaptation ability of plants against periodic flooding is hard to determine from genome band profile, but it is encoded by several genes in QTL genes related to water stress, enormously flooding stress. A study of C. annuum using resistance mutant plants showed that under waterlogging conditions, the plants expressed some genes related to hormone synthesis (Cap.ARATH, CapRAP2), antioxidant enzymes (Cap.POD), and adversity regulation (Cap.MYB1R1) [42]. Whereas, in soybean, 20 QTL had been reported associated with flooding stress traits [47]. In barley with a different hour of waterlogging periods stress, there were different genes expressed, i.e., genes induced by waterlogging were closely related to carbon and energy metabolism, nitrogen and amino acid metabolism, ROS scavengers, hormones-related genes, and transcription factors [48].
TABLE III

RAPD PROFILING OF 3 CAYENNE PEPPER CULTIVARS

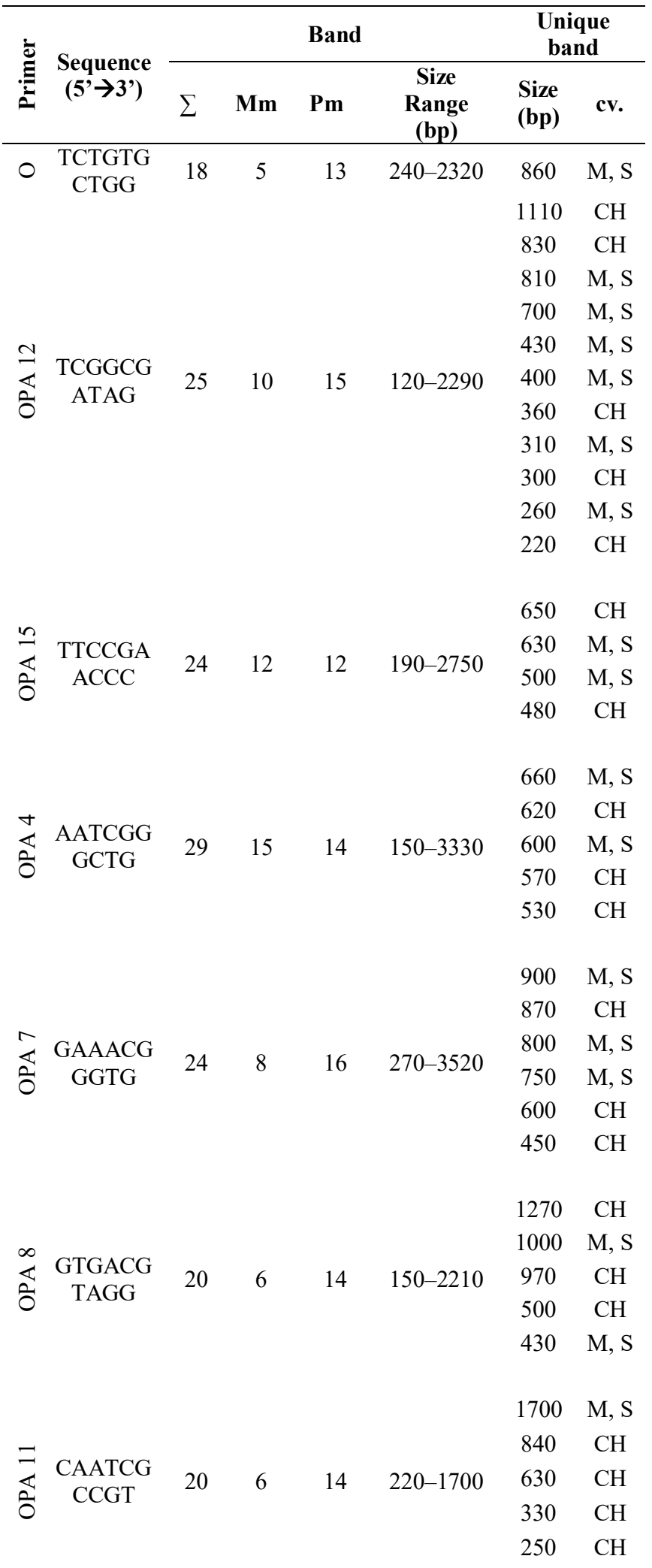

Note: $\sum=$ total band, $\mathrm{Mm}=$ monomorphic, $\mathrm{Pm}=$ Polymorphic, $\mathrm{cv} .=$ cultivars 
TABLE III

GENETIC SIMILARITY MATRIX ON TREATMENT AND CULTIVAR INTERACTION BASED ON JACCARD'S SIMILARITY TEST

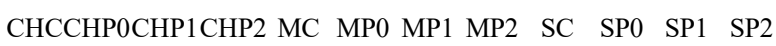

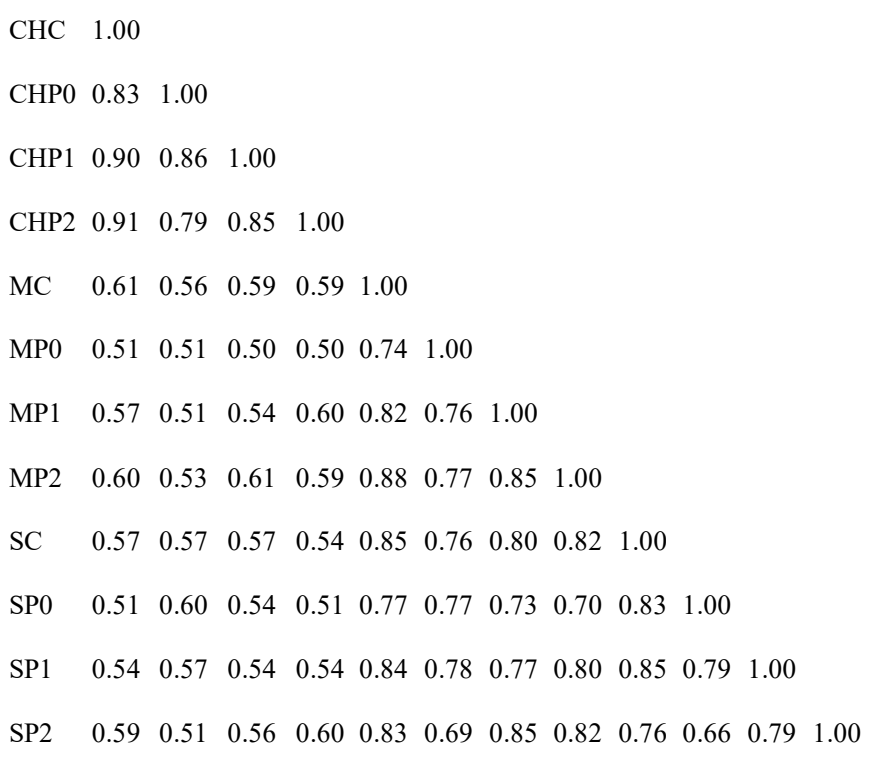

TABLE IIIV

REPRESENTATIVE OF DEATH AND SURVIVED TREATED PLANTS USED FOR RAPD PROFILING

\begin{tabular}{lll}
\hline Cultivars & Plant treatment & Status \\
\hline \multirow{4}{*}{ Cakra Hijau } & CHC & Survive \\
& CHP0 & Survive \\
& CHP1 & Survive \\
& CHP2 & Survive \\
Mhanu XR & MP0 & Survive \\
& MP1 & Survive \\
& MP2 & Death \\
Sret & SC & Death \\
& SP0 & Survive \\
& SP1 & Survive \\
& SP2 & Death \\
\hline
\end{tabular}

Genetic diversity among cayenne pepper cultivars can be a valuable germplasm candidate for breeding programs to develop cultivars with a good yield that are more adaptable to environmental stress, especially climate change. Knowledge of genetic diversity provides valuable information for germplasm resources management required in breeding programs [49], [50]. Crossbreed over species is needed to expand genetic diversity [1], [51] and to promote better production and improve resistance to biotic and abiotic stress [52].

\section{CONCLUSIONS}

Periodic flooding inhibited plant height growth, branch number, led to plant death, and decreased the potential of fruit number in cayenne pepper plants. $\mathrm{CH}$ had better endurance against periodic flooding than $\mathrm{M}$ and $\mathrm{S}$. RAPD techniques can be used to distinguish cayenne pepper cultivars with more endurance characteristics against flooding stress.

\section{NOMENCLATURE}

$\begin{array}{ll}\text { bp } & \text { base pair } \\ \text { cV } & \text { cultivars } \\ \text { Mm } & \text { monomorphic } \\ \text { OPA } & \text { operon A } \\ \text { Pm } & \text { polymorphic } \\ \text { QTL } & \text { a quantitative trait locus } \\ \text { rpm } & \text { revolutions per minute }\end{array}$

UPGMA unweighted pair group method with arithmetic mean

\section{Greek letters \\ $\sum_{\mathrm{O}} \quad \begin{aligned} & \text { total band } \\ & \text { degree }\end{aligned}$}

\section{ACKNOWLEDGMENT}

The authors are grateful to Indonesia Endowment Fund for Education (Lembaga Pengelola Dana Pendidikan), Ministry of Finance Affairs of Indonesia, for the research grant through BUDI-DN. We also thank Hesti Kurniahu, S. Si., M. Si., Elok Rifqi Firdiana, S.Si., M.Si., Nur Rahmatullah, S.Si. for their technical supports and Priwanto Arifin, S. Si. for assistance in statistical analysis.

\section{REFERENCES}

[1] E. L. Arumingtyas, J. Kusnadi, D. R. T. Sari, and N. Ratih, "Genetic variability of Indonesian local chili pepper: The facts," in AIP Conference Proceedings, 2017, vol. 1908, no. November 2017, pp. 110, doi: 10.1063/1.5012726.

[2] A. Pratiwi and S. Sugianto P.R, "The effect of water stress on growth and capsaicin content of cayenne pepper (Capcisum frutences L.)," $J$. Appl. Environ. Biol. Sci, vol. 7, no. 6, pp. 76-80, 2017, [Online]. Available: https://www.textroad.com/pdf/JAEBS/J. Appl. Environ. Biol. Sci., 7(6)76-80, 2017.pdf.

[3] D. Armita, E. L. Arumingtyas, and R. Mastuti, "Tolerance level of three genotypes of cayenne pepper (Capsicum frutescens L.) toward drought stress of vegetative phase based on morphological and physiological responses," Int. J. ChemTech Res., vol. 10, no. 2, pp. 183-192, 2017, [Online]. Available: http://www.sphinxsai.com/2017/ch_vol10_no2/1/(183192)V10N2CT.pdf.

[4] M. R. Pahlevi, S. Indriyani, R. Mastuti, and E. L. Arumingtyas, "Flooding effect to Capsicum frutescens L. in wilting and death perspectives," AIP Conf. Proc., vol. 2120, no. July, pp. 03001010300105, 2019, doi: 10.1063/1.5115614.

[5] A. Hakim, M. Syukur, and Y. Wahyu, "Evaluation of qualitative and quantitative characters 20 genotypes of bird pepper (Capsicum frutescens L.) IPB collection," Comm. Hortic. J., vol. 2, no. 1, pp. 20 27, 2018, doi: 10.29244/chj.2.1.20-27.

[6] A. Mustroph, "Improving flooding tolerance of crop plants," Agronomy, vol. 8, no. 9, p. 160, 2018, doi: 10.3390/agronomy8090160.

[7] K. Bhutia L, K. VK, T. Meetei NG, and N. Bhutia D, "Effects of climate change on growth and development of chilli," Agrotechnology, vol. 07, no. 02, pp. 1-4, 2018, doi: 10.4172/2168-9881.1000180.

[8] T. Fukao, B. E. Barrera-Figueroa, P. Juntawong, and J. M. Peña-Castro, "Submergence and waterlogging stress in plants: a review highlighting research opportunities and understudied aspects," Front. Plant Sci., vol. 10, no. March, pp. 1-24, 2019, doi: 10.3389/fpls.2019.00340.

[9] C. Wongs-Aree and S. Noichinda, "Glycolysis fermentative byproducts and secondary metabolites involved in plant adaptation under hypoxia during pre- and postharvest," in Hypoxia and Anoxia, K. K. Das and M. S. Biradar, Eds. IntechOpen, 2018, pp. 59-71.

[10] H. Huang, F. Ullah, D.-X. Zhou, M. Yi, and Y. Zhao, "Mechanisms of ROS regulation of plant development and stress responses," Front. Plant Sci., vol. 10, no. June, pp. 1-10, 2019, doi: 10.3389/fpls.2019.00800.

[11] F. Collin, "Chemical basis of reactive oxygen species reactivity and involvement in neurodegenerative diseases," Int. J. Mol. Sci., vol. 20, no. 10, pp. 1-17, 2019, doi: 10.3390/ijms20102407. 
[12] M. Lal, A. Kumari, Pooja, and S. Sheokand, "Reactive oxygen species, reactive nitrogen species and oxidative metabolism under waterlogging stress," in Reactive oxygen, nitrogen and sulfur species in plants: production, metabolism, signaling and defense mechanisms, Volume 2., M. Hasanuzzaman, V. Fotopoulos, K. Nahar, and M. Fujita, Eds. Pondicherry: Wiley-Blackwell, 2019, pp. 779-783.

[13] A. Salvatierra, G. Toro, P. Mateluna, I. Opazo, M. Ortiz, and P. Pimentel, "Keep calm and survive: Adaptation strategies to energy crisis in fruit trees under root hypoxia," Plants, vol. 9, no. 9, pp. 1-25, 2020, doi: 10.3390/plants9091108.

[14] J. C. Begara-Morales, M. Chaki, R. Valderrama, C. Mata-Pérez, M. Padilla, and J. B. Barroso, "Transcriptional regulation of gene expression related to hydrogen peroxide (H2O2) and nitric oxide (NO)," in Nitric Oxide and Hydrogen Peroxide Signaling in Higher Plants, D. K. Gupta, J. M. Palma, and F. J. Corpas, Eds. Cham: Springer Nature Switzerland, 2019, pp. 69-90.

[15] A. L. Villagómez-Aranda, L. F. García-Ortega, I. Torres-Pacheco, and R. G. Guevara-González, "Whole-genome DNA methylation analysis in hydrogen peroxide overproducing transgenic tobacco resistant to biotic and abiotic stresses," Plants, vol. 10, no. 1, p. 178, 2021, doi: 10.3390/plants10010178.

[16] A. Choudhary, A. Kumar, and N. Kaur, "ROS and oxidative burst: roots in plant development," Plant Divers., vol. 42, no. 1, pp. 33-43, 2020, doi: 10.1016/j.pld.2019.10.002.

[17] B. Sikora and P. Nowaczyk, "Application of RAPD technique for identification of interspecific hybrids from genus Capsicum," Acta Sci. Pol. Hortorum Cultus, vol. 13, no. 1, pp. 155-166, May 2014, [Online]. Available: http://www.hortorumcultus.actapol.net/pub/13 1 155.pdf.

[18] R. Dolkar, P. Kumar, M. Girigowda, and P. HM, "Assessment of genetic diversity in advance breeding lines of chilli (Capsicum annuum L.) using RAPD and cytochrome P 450 gene based marker system," Int. J. Chem. Stud., vol. 7, no. 2, pp. 1656-1663, 2019, [Online]. Available:

http://www.chemijournal.com/archives/2019/vol7issue2/PartAB/7-1 295-636.pdf.

[19] P. Renganathan, R.-A. C, H.-M. LG, P. Duraisamy, and R.-P. EO, "Evaluation of genetic diversity in germplasm of paprika (Capsicum spp.) using Random Amplified Polymorphic DNA (RAPD) markers,' J. Plant Sci. Phytopathol., vol. 1, no. 2, pp. 080-086, 2017, doi: 10.29328/journal.jpsp.1001010.

[20] A. A. Devi, N. Brajendra, and M. Dinachandra, "Genetic diversity analysis in chilli (Capsicum annuum L.) found in Manipur using RAPD markers," Int. J. Curr. Microbiol. Appl. Sci., vol. 7, no. 10, pp. 257-262, 2018, doi: 10.20546/ijcmas.2018.710.027.

[21] S. Tiwari, S. Sao, A. Kurrey, and P. Das, "Isolation and identification of molecular markers for fingerprinting of chilli hybrids \& its parental lines," Int. J. Res. Pharm. Sci., vol. 11, no. 1, pp. 713-716, 2020, doi: 10.26452/ijrps.v11i1.1883.

[22] U. U. Pujar, S. Tirakannanavar, R. C. Jagadeesha, and N. Sandhyarani, "Hybrid Purity Testing of Chilli Hybrid (Pusa Jwala $\times$ Arka Lohit) through RAPD and ISSR Molecular Markers," Int. J. Curr. Microbiol. Appl. Sci., vol. 6, no. 11, pp. 2079-2086, 2017, doi: 10.20546/ijcmas.2017.611.245.

[23] Sundari, E. L. Arumingtyas, L. Hakim, R. Azrianingsih, and D. Wahyudi, "Genetic variability of local durian (Durio zibethinus Murr.) in Ternate island based on RAPD markers," Plant Cell Biotechnol. Mol. Biol., vol. 18, no. 1\&2, pp. 68-75, 2017.

[24] Rosmaina, D. Mulyadi, R. Elfianis, and Zulfahmi, "Genetic diversity of chili pepper (Capsicum annuum L.) mutants (M-2) revealed by RAPD markers," J. Agroteknologi, vol. 10, no. 2, pp. 92-101, 2020 , [Online]. Available: http://ejournal.uinsuska.ac.id/index.php/agroteknologi/article/download/8780/4896.

[25] E. Sujitno and M. Dianawati, "Harvest production of many new varieties of Capsicum frutescens in dry land on Garut District, West Java," Pros Sem Nas Masy Biodiv Indon, vol. 1, no. 4, pp. 874-877, 2015, doi: $10.13057 / \mathrm{psnmbi} / \mathrm{m} 010438$.

[26] Susilawati, R. A. Suwignyo, Munandar, and M. Hasmeda, "Agronomic and physiological characteristics of red chilli varieties under waterlogging stress," J. Agron. Indones. (Indonesian J. Agron. vol. 40, no. 3, pp. 196-203, 2012, doi: 10.24831/jai.v40i3.6826.

[27] Susilawati, R. A. Suwignyo, Munandar, and M. Hasmeda, "Agronomic Characteristics and Tolerance of Red Chili Varieties under Water Logging Stress during Generative Phases," J. Lahan Suboptimal, vol. 1, no. 1, pp. 22-30, 2012, [Online]. Available: http://www.jlsuboptimal.unsri.ac.id/index.php/jlso/article/view/5/3.

[28] B. G. Tamang and T. Fukao, "Plant adaptation to multiple stresses during submergence and following desubmergence," Int. J. Mol. Sci., vol. 16, no. 12, pp. 30164-30180, 2015, doi: 10.3390/ijms161226226.

[29] E. Yeung, J. Bailey-Serres, and R. Sasidharan, "After The Deluge: Plant Revival Post-Flooding," Trends Plant Sci., vol. 24, no. 5, pp. 443-454, 2019, doi: 10.1016/j.tplants.2019.02.007.

[30] K. K. Bashar, "Hormone dependent survival mechanisms of plants during post-waterlogging stress," Plant Signal. Behav., vol. 13, no. 10 pp. 1-5, 2018, doi: 10.1080/15592324.2018.1529522.

[31] X.-S. Chen et al., "Differential strategies to tolerate flooding in Polygonum hydropiper plants originating from low-and high-elevation habitats," Front. Plant Sci., vol. 9, no. 1970, pp. 1-7, 2019, doi: 10.3389/fpls.2018.01970

[32] V. Ezin, R. De La Pena, and A. Ahanchede, "Flooding tolerance of tomato genotypes during vegetative and reproductive stages," Brazilian J. Plant Physiol., vol. 22, no. 1, pp. 131-142, 2010, doi: 10.1590/S1677-04202010000200007.

[33] A. A. Erhenhi, E. E. Lemy, D. E. Vwioko, and O. Imene, "Growth of Tomato (Solanum lycopersicum L.) under Waterlogging Condition," Eur. J. Sci. Res., vol. 152, no. 4, pp. 509-515, 2019, [Online]. Available:

https://www.europeanjournalofscientificresearch.com/issues/PDF/EJ SR 152_4_09.pdf.

[34] T. Nurhidayati, S. P. Wardhani, H. Purnobasuki, S. Hariyanto, N. Jadid, and D. D. Nurcahyani, "Response morphology and anatomy of tobacco (Nicotiana tabacum L.) plant on waterlogging," AIP Conf. Proc., vol. 1908, no. November, 2017, doi: 10.1063/1.5012723.

[35] M. Ghulamahdi, S. R. Chaerunisa, I. Lubis, and P. Taylor, "Response of five soybean varieties under saturated soil culture and temporary flooding on tidal swamp," Procedia Environ. Sci., vol. 33, pp. 87-93, 2016, doi: 10.1016/j.proenv.2016.03.060.

[36] Q. Zhang, E. J. W. Visser, H. De Kroon, and H. Huber, "Life cycle stage and water depth affect flooding-induced adventitious root formation in the terrestrial species Solanum dulcamara," Ann. Bot., vol. 116, no. 2, pp. 279-290, 2015, doi: 10.1093/aob/mcv095.

[37] T. C. Barickman, C. R. Simpson, and C. E. Sams, "Waterlogging causes early modification in the physiological performance, carotenoids, chlorophylls, proline, and soluble sugars of cucumber plants," Plants, vol. 8, no. 160, pp. 1-15, 2019, doi https://doi.org/10.3390/plants8060160.

[38] M. Sauter, "Root responses to flooding," Curr. Opin. Plant Biol., vol. 16, no. 3, pp. 282-286, 2013, doi: 10.1016/j.pbi.2013.03.013.

[39] P. K. Patel, A. K. Singh, N. Tripathi, D. Yadav, and A. Hemantaranjan, "Flooding: abiotic constraint limiting vegetable productivity," $A d v$. Plants Agric. Res., vol. 1, no. 3, pp. 96-103, 2014, doi 10.15406/apar.2014.01.00016

[40] A. P. Devi, M. S. Singh, S. P. Das, and J. Kabiraj, "Effect of climate change on vegetable production- a review," Int. J. Curr. Microbiol. Appl. Sci., vol. 6, no. 10, pp. 477-483, 2017, doi: 10.20546/ijcmas.2017.610.058.

[41] F. Aldana, P. N. García, and G. Fischer, "Effect of waterlogging stress on the growth, development and symptomatology of cape gooseberry (Physalis peruviana L.) plants," Rev. la Acad. Colomb. Ciencias Exactas, Físicas y Nat., vol. 38, no. 149, pp. 393-400, 2014, doi $10.18257 /$ raccefyn. 114 .

[42] Y. Zhang, L. Ou, J. Zhao, Z. Liu, and X. Li, "Transcriptome analysis of hot pepper plants identifies waterlogging resistance related genes," Chil. J. Agric. Res., vol. 79, no. 2, pp. 296-306, 2019, doi: 10.4067/S0718-58392019000200296.

[43] D. Wahyudi, L. Hapsari, and S. Sundari, "RAPD Analysis for Genetic Variability Detection of Mutant Soybean (Glycine max (L.) Merr)," J. Trop. Biodivers. Biotechnol., vol. 5, no. 1, p. 68, 2020, doi: $10.22146 /$ jtbb.53653.

[44] D. Olszewska, A. Niklas-Nowak, and L. Nowaczyk, "Estimation of genetic divergence within androgenic regenerants of Capsicum annuum L. ATZ1 $\times$ C. frutescens $\mathrm{L}$. F1 plants using Random Amplified Polymorphic DNA markers," Biotechnologia, vol. 98, no. 3, pp. 175-182, 2017, doi: 10.5114/bta.2017.70795.

[45] M. F. Lima, S. I. C. Carvalho, C. F. Ragassi, L. B. Bianchetti, F. G. Faleiro, and F. J. B. Reifschneider, "Characterization of a pepper collection (Capsicum frutescens L.) from Brazil," Genet. Mol. Res., vol. 16 , no. 3 , pp. $1-18,2017$, doi: $10.4238 /$ gmr16039704.

[46] E. N. Khasna et al., "Polymorphism of Pun1 gene for pungency in Capsicum frutescens 'Cakra Hijau' Indonesian local pepper," AIP Conf. Proc., vol. 2002, no. August, 2018, doi: 10.1063/1.5050115.

[47] S. K. Dhungana et al., "Quantitative trait loci mapping for flooding tolerance at an early growth stage of soybean recombinant inbred line population," Plant Breed., vol. 139, no. 3, pp. 626-638, 2020, doi: $10.1111 /$ pbr. 12790 
[48] A. Borrego-Benjumea, A. Carter, J. R. Tucker, Z. Yao, W. Xu, and A Badea, "Genome-wide analysis of gene expression provides new insights into waterlogging responses in Barley (Hordeum vulgare L.)," Plants, vol. 9, no. 2, pp. 1-23, 2020, doi: 10.3390/plants9020240.

[49] H. E. Cuevas and L. K. Prom, "Evaluation of genetic diversity, agronomic traits, and anthracnose resistance in the NPGS Sudan sorghum core collection," BMC Genomics, vol. 21, no. 88, pp. 1-15, 2020, doi: 10.1186/s12864-020-6489-0.

[50] Z. Migicovsky, E. Warschefsky, L. L. Klein, and A. J. Miller, "Using living germplasm collections to characterize, improve, and conserve woody perennials," Crop Sci., vol. 59, pp. 2365-2380, 2019, doi: 10.2135/cropsci2019.05.0353

[51] N. F. F. Do Nascimento, E. R. Do Rêgo, M. F. Nascimento, C. H. Bruckner, F. L. Finger, and M. M. Do Rêgo, "Evaluation of production and quality traits in interspecific hybrids of ornamental pepper," Hortic. Bras., vol. 37, no. 3, pp. 315-323, 2019, doi: 10.1590/s0102053620190310 .

[52] J. Wei et al., "Production and identification of interspecific hybrids between pepper (Capsicum annuum L.) and the wild relative (Capsicum frutescens L.)," J. Agric. Sci. Technol., vol. 21, no. 3, pp. 761-769, 2019, [Online]. Available: http://jast.modares.ac.ir/article23-14895-en.html. 